\title{
The Sherman Anti-trust Law and Readjustment
}

\author{
By Rush C. Butler
}

Chairman Federal Trade Committee of the Chamber of Commerce of the United States of America

$\mathrm{N}$ this discussion I hope to make it clear that Congress would be 1 justified at this time in conferring upon a federal administrative agency the power to determine in advance whether any given agreement or combination violates the rule of the Sherman Law. Thus baldly stated the proposal may seem revolutionary. But it is not. It indicates nothing more than the next essential step in the evolution of federal legislation concerning the regulation of competition. Such proposed legislation and control will bring us only half way to the goal of ultimate desire long since attained in England where the rule of law is the same as in the United States, where no regulation is established to administer the law, where violations of the law do not constitute crimes, and where infrequent resort to the courts either by aggrieved persons or by the government conclusively proves that in practical application the law is in furtherance of and not in opposition to the public interest.

What is the rule of the Sherman Law? In effect only this as presently interpreted,- that agreements unreasonably restraining trade are unlawful. English-speaking people can take no exception to a rule of conduct so sound and so traditional. But in the United States the rule has been enacted in a federal statute which provides that violations thereof shall be deemed criminal offenses punishable by fine and imprisonment. No means are anywhere provided for finally determining, until years after any contract has been entered into, whether or not it violates the law.

The courts alone can decide the question. If some years after an agreement has been made the courts hold that it did unreasonably restrain trade, the crime has long since been irretrievably committed. A man knows definitely and certainly in advance that if he does certain things he commits murder and that he thereby becomes liable to the penalties prescribed by the criminal statute. Hence such a statute deters the commission of the 
crime of murder and is a wholesome statute. The facts constituting unreasonable restraints of trade have not been and cannot be catalogued. The facts in one case might clearly constitute unreasonable restraint of trade and the same facts in another case might constitute only a reasonable restraint or even no restraint at all. The result of such a state of complicated uncertainty is not only to keep men from violating the law, i.e., from entering into agreements unreasonably restraining trade, but to keep men from entering into any agreements restraining trade even though the restraints be reasonable and therefore lawful. Lawful agreements are commendable. If fear of the law keeps men from entering into lawful contracts the public interest is violated. The Sherman Law is the basis of such fear to a degree that cannot be overstated. It is, therefore, something more than a law-it is a power beyond the law.

It is advisable, if not necessary, to find a way to avoid this extra-legal violation of the public interest. I believe the way is clearly indicated. The legislative policy of Congress of the past few years indicates it; the attitude of our courts and commissions also points the way. The public is sympathetically awaiting remedial legislation. The department of the government charged with the duty of enforcing the law has accepted, by acquiescence at least if not otherwise, the judgment of parties to contracts restraining trade to the effect that their particular contracts were not unreasonable restraints, and it has accordingly instituted no legal proceedings based thereon. Then too we are just emerging from the new experiences forced upon us by the war. We have new viewpoints. We have learned that prices can be fixed, production limited, territory divided, and many other things tending to restrain trade can be done without loss of profit to the manufacturer or merchant, without injury to purchaser or consumer, and without causing either private or public injury.

A brief review of our federal legislative history having to do with the Sherman Law, of the contemporaneous conduct of persons or corporations subject thereto, and of the attitude of the federal authorities charged with the enforcement thereof, will tend to establish the point stated in the opening sentence of this discussion. 


\section{The Sherman Law and Contemporary History}

The Sherman Law was enacted in 1890.1 Its prohibitions are contained in the first three sections. In order to avoid confusion of ideas it should first be stated that up to the year 1911 the law was interpreted by the Supreme Court as making unlawful every contract restraining trade, but that in Standard Oil Company vs. United States, 221 U. S. 1, decided May 15, 1911, the court held the law to make unlawful only those contracts resulting in unreasonable restraints of trade.

The first case decided by the Supreme Court directly involving the Sherman Law was United States vs. E. C. Knight Co., 156 U. S. 1, decided January 21, 1895, in which the court held that under the facts in the case interstate commerce was not involved.

The second case decided by the Supreme Court was United States vs. Trans-Missouri Freight Association, 166 U. S. 290, decided March 22, 1897. In its opinion in this case the court by a divided vote of five to four held: (1) That the act applied to and covered common carriers by railroad, and (2) that the agreement complained of by the government violated the provisions of the act.

1 For handy reference the Sherman Law is herewith reprinted:

Sherman Law; or, Federal anti-Trust Law

(Act of July 2, 1890; 26 Stat. 209)

An Act to protect trade and commerce against unlauful restraints and monopolies.

Section 1. Be it enacted by the Senate and House of Representatives of the United States of America in Congress assembled. Every contract combination in the form of a trust or otherwise, or conspiracy, in the restraint of trade or commerce among the several States, or with foreign nations, is hereby declared to be illegal. Every person who shall make any such contract or engage in any such combination or conspiracy, shall be deemed guilty of a misdemeanor, and, on conviction thereof, shall be punished by fine not exceeding five thousand dollars, or by imprisonment not exceeding one year, or by both said punishments, in the discretion of the court.

Sec. 2. Every person who shall monopolize, or attempt to monopolize, or combine or conspire with any other person or persons, to monopolize any part of the trade or commerce among the several States, or with foreign nations, shall be deemed guilty of a misdemeanor, and on conviction thereof, shall be punished by fine not exceeding five thousand dollars, or by imprisonment not exceeding one year, or by both said punishments, in the discretion of the court.

Sec. 3. Every contract, combination in form of trust or otherwise, or conspiracy, in restraint of trade or commerce in any Territory of the United States or of the District of Columbia, or in restraint of trade or commerce 
The agreement referred to was entered into by a number of railway companies operating in western territory. The preamble to the agreement recited that it was entered into "for the purpose of mutual protection by establishing and maintaining reasonable rates, rules and regulations on all freight traffic both through and local." The carriers contended that the statute in declaring illegal every agreement in restraint of trade, meant only such agreements as are in unreasonable restraint of trade. Answering the contention, the court said:

The term is not of such limited signification. . . . . . When, therefore, the body of an act pronounces as illegal every contract or combination in restraint of trade or commerce among the several states, etc., the plain and ordinary meaning of such language is not limited to that kind of contract alone which is in unreasonable restraint of trade, but all contracts are included in such language and no exception or limitation can be added without placing in the act that which is omitted by Congress.

Every agreement in restraint of trade, whether the restraint was partial or complete, reasonable or unreasonable, was therefore held unlawful.

In United States vs. Joint Traffic Association, 171 U. S. 505, decided October 24, 1898, the Supreme Court sustained its ruling

between any such Territory and another, or between any such Territory or Territories and any State or States or the District of Columbia, or with foreign nations, or between the District of Columbia and any State or States or foreign nations, is hereby declared illegal. Every person who shall make any such contract or engage in any such combination or conspiracy, shall be deemed guilty of a misdemeanor, and, on conviction thereof, shall be punished by a fine not exceeding five thousand dollars, or by imprisonment not exceeding one year, or by both said punishments, in the discretion of the court.

Sec. 4. That several circuit courts of the United States are hereby invested with jurisdiction to prevent and restrain violations of this act; and it shall be the duty of the several district attorneys of the United States, in their respective districts, under the direction of the Attorney General, to institute proceedings in equity to prevent and restrain such violations. Such proceedings may be by way of petition setting forth the case and praying that such violation shall be enjoined or otherwise prohibited. When the parties complained of shall have been duly notified of such petition the court shall proceed, as soon as may be, to the hearing and determination of the case; and pending such petition and before final decree, the court may at any time make such temporary restraining order or prohibition as shall be deemed just in the premises.

Sec. 5. Whenever it shall appear to the court before which any proceeding under section four of this act may be pending, that the ends of justice require 
in the Trans-Missouri case and held that thirty-one railroad companies, engaged in transportation between Chicago and the Atlantic Coast, which had formed an association and agreed that it should have jurisdiction over their competitive traffic and should fix rates, fares and charges, thereby violated the law.

With these two decisions of the Supreme Court squarely denying the right of interstate common carriers to establish rates and practices by agreement, it is a noteworthy fact that the carriers discontinued the practice only for a brief period if at all. They found that it was practically impossible for them to conduct their business without agreements as to rates and practices. Certainly as early as 1906 the practice of making rates by agreement was again resumed and was continued up to the time the government took control of the railroads in December, 1917. The practice was at no time between 1898 and 1917, so far as I know, challenged either directly or indirectly by the government, except incidentally in one proceeding.

The reason why the Department of Justice failed to proceed against the carriers for rate-making by agreement after the decisions in the Trans-Missouri case and the Joint Traffic case, and

that other parties should be brought before the court, the court may cause them to be summoned, whether they reside in the district in which the court is held or not; and subpoenas to that end may be served in any district by the marshal thereof.

Sec. 6. Any property owned under any contract or by any combination, or pursuant to any conspiracy (and being the subject thereof) mentioned in section one of this act, and being in the course of transportation from one State to another, or to a foreign country, shall be forfeited to the United States, and may be seized and condemned by like proceedings as those provided by law for the forfeiture, seizure, and condemnation of property imported into the United States contrary to law.

Sec. 7. Any person who shall be injured in his business or property by any other person or corporation by reason of anything forbidden or declared to be unlawful by this act, may sue therefor in any circuit court of the United States in the district in which the defendant resides or is found, without respect to the amount in controversy, and shall recover threefold the damages by him sustained, and the costs of suit, including a reasonable attorney's fee.

Sec. 8. That the word "person," or "persons" wherever used in this act shall be deemed to include corporations and associations existing under or authorized by the laws of either the United States, the laws of any of the Territories, the laws of any State, or the laws of any foreign country. 
prior to the Standard Oil case, is unknown, but it would probably not be far from the fact to say that such failure was due to the recognition by the Department of the necessity of such method of rate-making by the carriers, and to the Department's belief that the public interest was best served by failing to prosecute.

\section{Modification of the Law by Acts of Congress}

1. The Panama Canal Act, approved March 4, 1913, contained a provision prohibiting a railroad company from having any interest in a competitive water line, but further provided that the Interstate Commerce Commission was empowered to permit the continuation of any such ownership if it found that the water line was being operated in the public interest, was of advantage to the convenience and commerce of the people, and that the continuance of such ownership would not exclude, prevent or reduce competition on the water route. It is doubtful whether Congress had ever before recognized the principle that competition may be entrusted to regulation by an administrative body.

2. The Federal Trade Commission Act of September 26, 1914, declared that unfair methods of competition in commerce were unlawful, established the Federal Trade Commission, and conferred upon it the power to administer the law. There appears in this broad grant of power full and complete recognition by Congress of the principle that competition should not as a matter of right be free, but that it should be restricted and subjected to regulation. The commission was authorized to file a complaint against any person, firm or corporation deemed by it to be using any unfair method of competition if it appeared to the commission that the filing of such a complaint would be in the interest of the public. The commission was not required to deal with unfair methods merely trivial in character or affecting only individual or selfish interests. Its functions were to be exercised only in the regulation of such competition as affected the public. The principle thus recognized by Congress is in effect the same as that recognized by the Supreme Court in the Standard Oil case wherein it was held that contracts that did not unreasonably restrain trade, that is contracts not harmful to the public, were lawful.

While considering the Federal Trade Commission Law it may 
be appropriate to observe that the act places no limit upon the power of the Federal Trade Commission to determine as a matter of fact what is and what is not an unfair method of competition. The standard established by the Federal Trade Commission Act is no broader, however, than the standards established in Sections 1 and 3 of the Act to Regulate Commerce, declaring that all rates must be reasonable and not unduly prejudicial. The broader the standard, the less the difficulty of administration. In these two laws as well as in many others Congress has recognized the difficulty of limitation and definition. No catalog of specific acts could possibly be made which would clearly define either an unfair method of competition, a just and reasonable rate, or an unjust discrimination.

3. The Clayton Law, approved October 15, 1914, is defined in Section 1 thereof to be an anti-trust law. It establishes standards in that it declares to be unlawful:

(a) Price discrimination;

(b) Tying contracts; that is, sales agreements made with the understanding that the purchaser shall not use the goods, wares or merchandise of a competitor;

(c) Stock ownership of one corporation in another;

(d) Interlocking of directors.

Again in the Clayton Law the public interest is emphasized, for its prohibitions apply only in cases where the things forbidden would restrain commerce or tend to create a monopoly.

Authority to enforce compliance with the provisions of this law is vested in the Interstate Commerce Commission where applicable to common carriers; in the Federal Reserve Board where applicable to banks; and in the Federal Trade Commission where applicable to all other branches of commerce.

In addition to establishing these standards, the Clayton Law amends the Sherman Law in that it declares (Section 6):

That the labor of a human being is not a commodity or article of commerce. Nothing contained in the anti-trust laws shall be construed to forbid the existence and operation of labor, agricultural, or horticultural organizations, instituted for the purposes of mutual help, and not having capital stock or conducted for a profit, or to forbid or restrain individual members of such organizations from lawfully carrying out the legitimate objects thereof; nor shall such organizations, or the members thereof, be held or construed to be illegal combinations or conspiracies in restraint of trade, under the anti-trust laws. 
4. The Sundry Civil Appropriations Act, effective July 1, 1916, making appropriations for governmental expenses, contains the following provision with reference to appropriations for the Department of Justice in the enforcement of the anti-trust laws:

Provided, however, that no part of this money shall be spent in the prosecution of any organization or individual for entering into any combination or agreement having in view the increasing of wages, shortening of hours or bettering the conditions of labor, or for any act done in furtherance thereof, not in itself unlawful: provided further, that no part of this appropriation shall be expended for the prosecution of producers of farm products and associations of farmers who coöperate and organize in an effort to and for the purpose to obtain and maintain a fair and reasonable price for their products.

It is understood that the same provision has been carried in each subsequent sundry civil bill making the same appropriation carried in all appropriation bills. The apparent purpose of this legislation is to grant still further exemption of labor from the provisions penal and otherwise of the Sherman Law. Congress would no doubt justify this exemption on the ground that it was in the public interest. This provision also goes so far as to recognize the validity of agreements made by farmers for the purpose of obtaining and maintaining fair and reasonable prices for their products. Here Congress recognizes that it is in the public interest that producers be permitted to obtain fair and reasonable prices for the things produced,- or to state it conversely, that it is against the public interest for a person to sell his products at less than fair and reasonable prices. It is to be noted, however, that coöperation among farmers directed toward obtaining and maintaining prices that are higher than fair and reasonable prices is not exempted from the provisions of the Sherman Law.

5. By amendment to the Federal Reserve Act, September 7, 1916, national banks were given authority, subject to regulation by the Federal Reserve Board, to coöperate with each other in conducting banking business in foreign countries.

6. Effective the same date, the Shipping Board Act authorized American steamship lines to enter into such agreements fixing rates or restricting competition, as are approved by the Shipping Board and found by it not to be in violation of the standard established by the act,- - that is, not to operate to the detriment of American commerce. 
7. The Webb-Pomerene Act, approved April 10, 1918, exempts from the provisions of the Sherman Law contracts, agreements or combinations among persons or corporations doing business in the United States for the purpose of conducting export business only. This act specifically states that its provisions must not be used "artificially or intentionally" to affect domestic business. It also confers jurisdiction upon the Federal Trade Commission to supervise the conduct of export associations and their members, and applies the rule against unfair methods of competition to the conduct of export associations as related to American competitors in foreign markets. The Webb-Pomerene Law directly repeals the Sherman Law in so far as export business is concerned.

8. The United States in assuming control of the railroads accomplished one main purpose, viz., the unrestricted interchangeable use of the carriers' facilities. Under the law as it existed prior to the time the government assumed control of the railroads it would have been impossible for the responsible officers of transportation companies to permit the use of their terminal facilities by competitors or to allow diversion of traffic from their own to competitive lines. The Honorable Edgar E. Clark of the Interstate Commerce Commission recently recommended to the Senate Committee on Interstate Commerce the revision of limitations upon united and coöperative activities among common carriers with a view to eliminating wasteful and unduly expensive competition in rates and service. No man in public life is in better position than Mr. Clark to judge of the necessity for such legislation.

It may also be observed that the Department of Commerce in its active readjustment program for lines of general industry is likewise urging that competitors coöperate subject to certain regulation by the Department.

9. One of the provisions of the act of March 21, 1918, to provide for the operation of transportation systems while under federal control reads as follows:

In determining any question concerning any such rates, fares, charges, classifications, regulations, or practices or changes therein, the Interstate Commerce Commission shall give due consideration to the fact that the transportation systems are being operated under a unified and coördinated national control and not in competition. 
This provision seems to be another clear congressional recognition of the fact that competition may go to undue ends, and that it is not against the public interest for the carriers while united to make a higher charge for a service rendered than they had previously made under the compulsion of competition.

10. The Income Tax Law, approved September 8, 1916, section 801, provides that it shall be unlawful for any person exporting articles from any foreign country into the United States, under circumstances therein set out, to sell such articles at a price substantially less than the market value thereof, if the object is to destroy or injure an industry in the United States, or to prevent its establishment here, or to restrain or monopolize the trade in such articles in this country. Again we have in this law congressional recognition of the fact that prices may be made so low as to violate the public interest.

11. Another recognition of the same principle is found in the Lever Law, approved August 10, 1917, enacted "to provide further for the national security and defense, by encouraging the production, conserving the supply, and controlling the distribution of food products and fuel." The law provides among other things that:

In fixing maximum prices for producers, the Commission (Federal Trade Commission) shall allow the cost of production including the expense of operation, maintenance, depreciation and depletion, and shall add thereto a just and reasonable profit.

In fixing such prices for dealers the Commission shall allow the cost to the dealer and shall add thereto a just and reasonable sum for his profit in the transaction.

12. The Committee on Merchant Marine and Fisheries of the House of Representatives in a public report has expressed broad views on the general subject. The court in the United States vs. Hamburg-American S. S. Line, 216, Federal Reporter 971, said:

The main subject matter of the controversy, viz., the controlling of transportation so as to allot proportionate shares of it to the different defendants who are in the combination, has recently been most exhaustively considered by the standing committee on Merchant Marine and Fisheries under resolutions of the House of Representatives in Congress. It is manifest from its report that the committee had before it substantially the same evidence which is contained in the record in this case. There is nothing to add to the elaborate presentation of all sides of the controversy which will be found in that report, and we find it 
most persuasive to the conclusion that, in view of the peculiarities of ocean transportation, the method adopted by the defendants-if purged of its obnoxious feature, the "fighting" ship-is a reasonable one, which, so far from restraining trade, really fosters and protects it, by giving it a stability which insures more satisfactory public service for all concerned. Without this method, or something like it, there would be, in the language of the committee, one or other of two results:

The lines would either engage in rate wars which would mean the elimination of the weak and the survival of the strong, or to avoid a costly struggle they would consolidate through common ownership. Either would mean monopoly fully as effective, and it is believed more so, than can exist by virtue of (this) agreement.

It seems, therefore, that this particular combination comes fairly within the exception to a strictly literal construction of the statute, which is indicated in the Standard Oil and Tobacco cases.

This review of the attitude of Congress during the past few years as to the Sherman Law clearly establishes that the view of Congress as to the public interest has materially broadened; that Congress no longer feels that unrestricted competition is warranted as a governmental policy, and that regulation not only of restraints on competition but of restraints on contracts can well be entrusted to administrative bodies.

\section{Modification of the Sherman Law by War-Time Activities}

The creation of the price-fixing committee of the War Industries Board was not specifically authorized by statute but the committee was the outgrowth of the necessities of the situation. Neither was there any law authorizing the fixing of prices on many articles or commodities the prices of which were controlled directly or indirectly by the committee. In very large measure the prices fixed by the committee were determined or suggested by the producers or manufacturers. The government also placed many restrictions upon manufacturers and producers as to sizes, styles, amount of material permitted to be used, as well as limitations upon markets. Due to the controls so set up, the regulation of prices, production and markets was carried out in a manner satisfactory not only to the industries concerned but to the public at large.

In addition to such form of regulation, the government required of various industries as a war measure that they spend vast sums of money on existing plants in additions and improvements and 
in the construction and equipment of new plants. It was inevitable that at the close of the war, whenever that event might occur, there would be vast sums of money invested in the various industries affording productive capacity which would not thereafter be needed, and which would almost certainly menace the industrial peace of the nation. That there has been no panic since the signing of the armistice is a tribute to the good sense and sane judgment of the business men of the country. How long they will be able to hold the situation in check cannot be known, but it seems certain that sooner or later the government must act in the public interest, at least to the extent of permitting competitors to agree to restrict production.

\section{Suggested Remedy for Sherman Law Evils}

The remedy here suggested for the evils resulting from the Sherman Law is that Congress authorize an administrative body to determine in advance whether or not agreements between competitors in restraint of trade are or are not lawful. Let us see how such regulation would work in a concrete case. For example, take the coal-mining industry. It is a natural resource industry, and as such is a special care of the state, because it exhausts a supply that can never be replaced or restored. The Lever Law, approved August 10, 1917, was enacted "to provide further for the national security and defense by encouraging the production, conserving the supply, and controlling the distribution of food products and fuel." For twenty-five years prior to the war, with only two or three brief periods of prosperity, the coal industry was in a deplorable condition, due almost entirely to the fact that the capacity of the mines was largely in excess of that required to produce the coal that the people of the country consumed. Great as was that capacity, it was insufficient to meet the war-time demands made by the government upon the industry. Under the stimulation of the Lever Law, inspired by patriotic motives of the highest order, and being fully cognizant of the additional burden they would have to carry after the war as a result of increasing their productive capacity, the coal operators of the country responded to the demand of the President and the United States Fuel Administrator, and increased both capacity and output beyond all figures ever before known, only to find 
themselves today face to face with an economic crisis that cannot be permanently averted without Congressional action. If agreements among competitors fixing prices, curtailing production, and limiting territory in which they may sell their products may be entered into with impunity, the problems of the coal operators and of those interested in many other lines of industry can, with the assistance of the government, be easily solved.

Assume that by authority of Congress coal operators were permitted to enter into agreements in restraint of trade subject to approval by an administrative agency of the government and to regulation by it. Assume that the administrative agency had found a particular agreement to be only in reasonable restraint of trade and therefore approved it in the public interest. Assume further that the agreed prices yielded the operators only a fair and reasonable profit enabling them to pay the miner fair wages and to sell their coal at a cost that was not unreasonable to consumers thereof. And finally assume that the over-capacity of the mines in the absence of the approved agreement would have resulted in irregular running time, unemployment and consequent labor disturbances, cut-throat competition and financial loss to the industry as a whole and irreparable damage to coal-mining communities.

Under these assumptions it is fair to conclude that the following among other results would be accomplished in the public interest if the agreements were permitted by the regulating body to become effective:

1. There would be conservation of natural coal resources. With a fair margin of profit allowed the operator, the temptation to mine coal as cheaply as possible without regard to conservation methods would be largely overcome. I have been reliably informed that one large operating company, knowing that the price of its output as established by the United States Fuel Administration would yield a fair margin of profit, adopted measures of conservation that increased the percentage of realization of the natural resources in the ground from an average 70 per cent thereof mined under pre-war competitive conditions to $8 \mathcal{2}$ per cent thereof produced under governmental regulation.

2. Conservation of health and life of the miners would be promoted by the ability to adopt more careful methods of operation and to install modern and improved machinery. 
3. Better preparation of coal by cleaning would be insured. Slate, rock and other impurities would be removed at the mine. This would avoid the use of the carriers' transportation facilities to the extent of the bulk and weight so removed, and would tend to relieve car-shortage and would materially decrease transportation charges.

4. Cleaning the coal would also result in greater cleanliness in firing and would reduce the consumers' expense of operation, maintenance and repairs.

5. Greater attention could also be given to preparation of sizes to suit the demands of consumers whose plants are equipped to handle only certain sizes of coal.

6. The profit to the operator would be in the public interest. It is now conceded to be in the interest of the public that goods and products be sold and handled so as to yield a margin of profit. It is considered to be against the public interest to compel or even to permit competitive prices to become so low as to be less than the cost of manufacturing or producing. This principle has been recognized by the Federal Trade Commission in several complaints it has filed. In complaints filed against the manufacturers of mail chutes the only violation of law alleged by the commission is that an unfair method of competition was used by the manufacturers in that they sold and are selling their product "at and for a price which is less than the cost of producing the same."

7. Curtailment of production would not be so handled as to shut down completely any mine desiring to operate, but would equitably distribute the burden of lack of business among the operators.

8. Regulation of production would also permit the seasonable handling and movement of coal, allowing it to move regularly throughout the year, making provisions for storage, regularity of production, distribution and supply.

9. Labor would be afforded regular, if not daily employment, and at living wages.

10. Coal operators working under such governmental regulation would be in position to coöperate with the common carriers serving their mines. This would result in minimizing, if not eliminating, car-shortage periods and congestion of the tracks and facilities of the carriers. 
11. The establishment of zones would keep lower grade coals nearer points of production and permit wider and perhaps unlimited movement of special quality coals, such as cannel, smithing, smokeless and anthracite. This would avoid cross-hauling with all its attendant economic evils.

12. The government is obviously interested these days in the substantial prosperity of all lines of industry. It derives the money with which to discharge its vast financial obligations in part from income and excess profits taxes and in part from the sale of bonds. If the coal industry, for example, does not prosper, the government's revenues realized from income taxes paid by coal companies will be small indeed and its revenues from excess profits taxes will be so small as to be negligible. Unless the industry prospers it will have no money with which to buy bonds.

All of the results above enumerated may reasonably be expected to flow from the regulation suggested and are all in the public interest.

The proposed legislation conferring authority upon an administrative body to approve or disapprove in advance agreements in restraint of trade would be in accord with our well-defined legislative policy. The rule of the Sherman Law is not objectionable. Repeal of the criminal provisions of the Sherman Law would be an obvious remedy for its resulting evils, but such amendment would not be in accord with our legislative policy and is therefore not suggested. The administrative body authorized to approve such agreements would naturally be composed of men well versed in business affairs and the laws applicable thereto. Their views concerning questions of public interest would be broad, and could reasonably be expected to be sympathetic. Their decisions could keep abreast of national policy much more easily than could legislative enactment. The facts constituting violations of the law would be made known in advance to all concerned and the extra-legal restraints upon lawful enterprise would disappear. The Federal Trade Commission in the nature of things is the agency to which the suggested authority should be entrusted. Though its jurisdiction would thereby be enlarged, its functions would not be materially changed. The Commission already possesses ample jurisdiction concerning trade practices. Agreements in restraint of trade, whether they be lawful or unlawful, 
are so closely related to trade practices that it would be folly to create a new or a different body to administer the proposed new law.

The condition in which business finds itself at the present time is not substantially different than it was when President Wilson addressed Congress, January 20, 1914, recommending the enactment of the Federal Trade Commission Law. The President then said:

And the business men of the country desire something more than that the menace of legal process in these matters be made explicit and intelligible. They desire the advice, the definite guidance and the information which can be supplied by an administrative body, an interstate trade commission.

The opinion of the country would instantly approve of such a commission. It would not wish to see it empowered to make terms with monoply or in any sort to assume control of business, as if the Government made itself responsible. It demands such a commission only as an indispensable instrument of information and publicity, as a clearing-house for the facts by which both the public mind and the managers of great business undertakings should be guided, and as an instrumentality for doing justice to business where the processes of the courts or the natural forces of correction outside the courts are inadequate to adjust the remedy to the wrong in a way that will meet all the equities and circumstances of the case.

Congress in response to this recommendation of the President enacted the Federal Trade Commission Law and conferred upon the commission thereby created the broad powers herein above referred to.

The language of the President above quoted is equally applicable to existing conditions. Ours is a government of laws and not of men. If the principles upon which our legislative policy is based are sound, men of integrity, ability and vision can be found to administer these laws. The Federal Trade Commission as an institution is in accordance with current legislative policy. It is the judgment of many men whose opinions are entitled to respect that the Federal Trade Commission should be enlarged to not less than nine members, and that upon such enlarged commission Congress would be justified in conferring these additional powers of regulation. 